\title{
Effect of row and hill spacing on the yield performance of boro rice (cv. BRRI dhan45) under aerobic system of cultivation
}

\author{
M. R. Sultana, M. M. Rahman and M. H. Rahman \\ Department of Agronomy, Bangladesh Agricultural University, Mymensingh-2202, Bangladesh \\ Email: rahmanag63@yahoo.com
}

\begin{abstract}
An experiment was conducted at the Agronomy Field Laboratory, Bangladesh Agricultural University, Mymensingh during November 2008 to April 2009 to evaluate the effect of row and hill spacings on the yield of rice (cv. BRRI dhan45) under aerobic system of cultivation in boro season. Aerobic system is a new water efficient rice production system where the crop is grown by direct seeding on well prepared dry beds and also by maintaining the soil moisture at field capacity during the growing period. The experiment consisted of two row to row spacings viz. 20 and $25 \mathrm{~cm}$, and five hill to hill spacings viz., 2.5, 5, 10, 15 and $20 \mathrm{~cm}$. The trial was laid out in a randomized complete block design with 3 replications. Results revealed that the crop sown at $25 \mathrm{~cm} \times 15 \mathrm{~cm}$ produced the highest grain yield of $5.69 \mathrm{t} \mathrm{ha}^{-1}$ whereas the lowest grain yield of $2.11 \mathrm{t} \mathrm{ha}^{-1}$ was found with $20 \mathrm{~cm} \times 2.5 \mathrm{~cm}$ spacing. The present study concludes that the highest grain yield of BRRI dhan45 during boro season under aerobic system of cultivation could be achieved by sowing at $25 \mathrm{~cm} \times 15 \mathrm{~cm}$ spacing.
\end{abstract}

Keywords: Aerobic system, Boro rice, Hill spacing, Row spacing, Direct seeding

\section{Introduction}

Rice (Oryza sativa L.) is the most important food grain in Bangladesh. It is extensively cultivated throughout the year and it is also staple food crop in Bangladesh. Bangladesh is an agro based country; more than $80 \%$ population is directly dependent on agriculture. The soil and climate of Bangladesh are favorable for rice cultivation. In Bangladesh, about $77 \%$ of total cultivable land (14.42 million hectare) is used for rice cultivation. Boro rice is cultivated in about 4.7 million hectares of land and producing 18.6 million tons of rice (BBS, 2011). Rice is grown in three seasons namely aus, aman and boro. Boro rice occupies about $42 \%$ of total rice area contributing $55 \%$ of the total production. Therefore, boro rice is the main contributor to the food security in Bangladesh. Boro rice is mainly cultivated by puddled transplanting with flood irrigation. More than $80 \%$ of irrigation water comes from underground water source. The withdrawal of huge irrigation water causes lowering of ground water table and consequently causing serious environmental problems. The irrigation is done mainly by deep tubewell or shallow tubewells. Huge amount of electricity or diesel is required to operate these irrigation equipments. The scarcity of electricity or diesel in the country is increasing. The price of fuel is also increasing. Therefore, water saving boro rice production system is required under this water scarce to ensure food security. Currently, alternate wetting and drying (AWD) system of irrigation has been advocated towards saving irrigation water for boro rice but the water saving in this system is about $20-25 \%$ (Satter, 2009). On the other hand, 'aerobic system of rice cultivation' has been developed very recently where rice can be grown successfully with saving of 50-70\% irrigation water (Bouman et al., 2005, Peng et al., 2006). In aerobic rice system, rice is grown by direct seeding on well prepared unpuddled soil with supplemental irrigation. Unlike upland rice, the rice plant is highly responsive to inputs in aerobic system and the crop can produce similar yield to that of conventionally puddled transplanted system. Since, aerobic system offers water savings in rice cultivation, it could be adopted to sustain higher yield with less water in lowland boro rice production system towards attaining food security (Zhao et al., 1998).

Planting density is one of the most important factors determining the yield of rice. The growth, development and yield of rice are greatly influenced by plant spacing under field condition. Some farmers use close spacing while others use wide spacing. Closer spacing hampers intercultural operations, increases competition among the plants for nutrients, air, light, which results in weaker plants, mutual shading thus favours more straw yield than grain yield. On the other hand, wider plant spacing reduces grain yield unit ${ }^{-1}$ area. Optimum plant spacing ensures the plant to grow properly with their aerial and underground parts by utilizing more solar radiation and nutrients (Miah et al., 1990). The maximum benefit in respect of rice yield can be obtained where planting is done with proper spacing. Many research 
reports are available regarding the effect of spacing in conventionally transplanted rice cultivation in boro season (Miah et al., 1990, Verma et al., 2002; Rahman et al., 2004; Rahman and Taher, 2008; Rahman et al., 2008) but research reports relating to the effect of plant density on boro rice production under aerobic system of cultivation is scarce. With view to the above discussion, an experiment was conducted aiming at evaluating the effect of row to row and hill to hill spacing on the yield performance of rice $\mathrm{cv}$. BRRI dhan45 in boro season towards selecting the best spacing for rice under aerobic system of cultivation.

\section{Materials and Methods}

An experiment was conducted at the Agronomy Field Laboratory, Bangladesh Agricultural University, Mymensingh during November 2008 to April 2009. The area is located at $24^{\circ} 75^{\prime} \mathrm{N}$ latitude, $90^{\circ} 50^{\prime} \mathrm{E}$ longitude and at an altitude of $18 \mathrm{~m}$. The land was medium high with moderate drainage facility and the soil was silt loam with $\mathrm{pH}$ value of 5.77 . Soil contained $1.027 \%$ organic matter, $0.09 \%$ total $\mathrm{N}, 5.68 \mathrm{ppm}$ available $\mathrm{P}, 49.12 \mathrm{meq} 100 \mathrm{~g} \mathrm{~g}^{-1}$ exchangeable $\mathrm{K}$ and $82.8 \mathrm{ppm}$ available $\mathrm{S}$. The boro season is colder with scanty rainfall. The study was conducted with a view to evaluate the effect of row and hill spacings on the yield of performance rice (cv. BRRI dhan45) under aerobic system of cultivation in Boro season. The experiment comprised (a) two row to row spacing viz., 20 and $25 \mathrm{~cm}$, and (b) five hill to hill spacings viz., $2.5,5,10,15$ and $20 \mathrm{~cm}$. The trial was laid out in a randomized complete block design with 3 replications. The unit plot size was $4.0 \mathrm{~m} \times 3.0 \mathrm{~m}$ and the distances between blocks and unit plots were $1.0 \mathrm{~m}$ and $0.75 \mathrm{~m}$, respectively. The land was prepared by country plough at field capacity and the sowing was done on 29 November 2008. The land was applied with 10 tons of cowdung at the time of land preparation. Fertilizers were applied @ 104, 15, 60, 15 and $1.5 \mathrm{~kg} \mathrm{~N}, \mathrm{P}, \mathrm{K}, \mathrm{S}$ and Zn, respectively in the form of urea, triple super phosphate, muriate of potash, gypsum and zinc sulphate. All the fertilizers except urea were applied during final land preparation. Urea was applied in four equal splits at 15, 30, 45 and 60 days after sowing. Seeds were primed by soaking in water for $24 \mathrm{~h}$ at room temperature followed by incubation at 35 ${ }^{\circ} \mathrm{C}$ for $30 \mathrm{~h}$. After surface drying under shade, the primed seeds were dibbled directly in rows in the main field allocating four seeds hill ${ }^{-1}$ as per experimental specification. Three hand weeding were done at 25, 50 and 60 days after sowing to control weeds. Experimental plots were irrigated 14 times to maintain normal growth and development of the crop. The soil was maintained at aerobic conditions during whole period of the season except for panicle initiation to flowering stage where wet condition was maintained. The crop was hand harvested at maturity. The harvesting was done on 29 April 2009 from the central $3 \mathrm{~m}$ x $2 \mathrm{~m}$ area. Five hills (excluding border hills) were randomly selected in each plot and uprooted before harvesting to record necessary data on various plant characters and yield attributes. The collected data on yield, plant characters and yield related attributes were analyzed statistically by using "Analysis of Variance Technique" and the means were compared following DMRT with the help of a statistical package programme MSTAT-C.

\section{Results and Discussion}

\section{Effect of row to row spacing}

The row to row spacing had significant effect on yield and yield contributing characters of rice (Table 1). Number of effective tillers hill ${ }^{-1}$, non-effective tillers hill $^{-1}$ and sterile spikelet hill ${ }^{-1}$ were affected significantly by row to row spacing while plant height, number of total tillers, panicle length, 1000-grain weight and harvest index remained unaffected. Higher grain yield $\left(4.35 \mathrm{t} \mathrm{ha}^{-1}\right)$ was obtained from $25 \mathrm{~cm}$ apart row spacing due to the increased number of effective tillers hill ${ }^{-1}$ (13.11). Higher straw yield $\left(5.56 \mathrm{t} \mathrm{ha}^{-1}\right)$ and biological yield $\left(9.89 \mathrm{t} \mathrm{ha}^{-1}\right)$ were obtained from $20 \mathrm{~cm}$ apart row spacing. The result is partially coincided with the result of Jalil (2008) who stated that the crop (cv.BRRI dhan29) with $25 \mathrm{~cm}$ row to row spacing produced the highest grain yield $\left(5.87 \mathrm{t} \mathrm{ha}^{-1}\right)$ under aerobic system of cultivation. Lower grain yield (4.3t $\mathrm{ha}^{-1}$ ) was obtained from $20 \mathrm{~cm}$ apart row spacing due to fewer effective tillers hill ${ }^{-1}$ (12.8) and spikelets panicle $^{-1}(108.41)$. Lower straw yield $\left(5.45 \mathrm{t} \mathrm{ha}^{-1}\right)$ and biological yield $\left(9.82 \mathrm{t} \mathrm{ha}^{-1}\right)$ were obtained from 25 $\mathrm{cm}$ apart row spacing. 
Table 1. Effect of row to row and hill to hill spacing on crop characters, yield and yield related parameters of BRRI dhan45 under aerobic system of cultivation in boro season

\begin{tabular}{|c|c|c|c|c|c|c|c|c|c|c|c|c|}
\hline Spacing & $\begin{array}{l}\text { Plant } \\
\text { height } \\
(\mathrm{cm})\end{array}$ & $\begin{array}{c}\text { Total } \\
\text { tillers } \\
\text { hill-1 }^{-1} \text { (no.) } \\
\end{array}$ & $\begin{array}{c}\text { Effective } \\
\text { tillers hill-1 } \\
\text { (no.) }\end{array}$ & $\begin{array}{l}\text { Non-effective } \\
\text { tillers hill-1 } \\
\text { (no.) }\end{array}$ & $\begin{array}{l}\text { Panicle } \\
\text { length } \\
\text { (cm) }\end{array}$ & $\begin{array}{c}\text { Grains } \\
\text { panicle-1 } \\
\text { (no.) }\end{array}$ & $\begin{array}{c}\text { Sterile } \\
\text { spikelets } \\
\text { panicle-1 (no.) }^{-1}\end{array}$ & $\begin{array}{l}\text { 1000-grain } \\
\text { weight }(\mathrm{g})\end{array}$ & $\begin{array}{c}\text { Grain } \\
\text { yield } \\
\left(\mathrm{t} \mathrm{ha} \mathrm{a}^{-1}\right)\end{array}$ & $\begin{array}{c}\text { Straw } \\
\text { yield } \\
\left(\mathrm{t} \mathrm{ha}^{-1}\right)\end{array}$ & $\begin{array}{c}\text { Biological } \\
\text { yield } \\
\left(\mathrm{t} \mathrm{ha}^{-1}\right) \\
\end{array}$ & $\begin{array}{c}\text { Harvest } \\
\text { index } \\
(\%)\end{array}$ \\
\hline \multicolumn{13}{|c|}{ Row to row spacing } \\
\hline $20 \mathrm{~cm}$ & 86.98 & 18.49 & $12.80 \mathrm{~b}$ & $5.69 b$ & 21.88 & 108.41 & $15.74 b$ & 24.93 & $4.3 \mathrm{~b}$ & $5.56 \mathrm{a}$ & $9.86 \mathrm{a}$ & 42.73 \\
\hline $25 \mathrm{~cm}$ & 87.52 & 19.03 & $13.11 \mathrm{a}$ & $5.92 a$ & 22.49 & 114.96 & $16.75 a$ & 24.78 & $4.35 \mathrm{a}$ & $5.47 \mathrm{~b}$ & $9.82 b$ & 43.42 \\
\hline sX & 0.86 & 0.25 & 0.28 & 0.26 & 0.37 & 0.65 & 0.38 & 0.14 & 0.05 & 0.06 & 0.09 & 0.29 \\
\hline CV (\%) & 4.41 & 6.14 & 5.14 & 22.84 & 4.14 & 3.09 & 5.65 & 10.01 & 5.77 & 7.47 & 5.67 & 4.53 \\
\hline $\begin{array}{l}\text { Level of } \\
\text { Significance }\end{array}$ & NS & NS & ** & ** & NS & NS & ** & NS & ** & ** & ** & NS \\
\hline \multicolumn{13}{|c|}{ Hill to hill spacing } \\
\hline $2.5 \mathrm{~cm}$ & 87.35 & $17.16 \mathrm{~b}$ & 12.66 & $4.50 \mathrm{~b}$ & 22.05 & $82.50 \mathrm{e}$ & $27.83 a$ & 24.49 & 2.11d & $4.02 \mathrm{C}$ & $6.13 d$ & $34.44 \mathrm{c}$ \\
\hline $5 \mathrm{~cm}$ & 87.48 & $17.25 b$ & 13.10 & $4.14 b c$ & 22.14 & 109.90d & $16.89 b$ & 25.08 & $4.47 \mathrm{~b}$ & $5.39 b$ & $9.86 \mathrm{~b}$ & $45.32 a$ \\
\hline $10 \mathrm{~cm}$ & 86.23 & $17.77 \mathrm{~b}$ & 15.01 & $2.76 \mathrm{~d}$ & 21.92 & $118.61 \mathrm{c}$ & $9.11 d$ & 24.71 & $5.46 a$ & $6.45 a$ & $11.92 a$ & $45.99 a$ \\
\hline $15 \mathrm{~cm}$ & 87.55 & $17.87 \mathrm{~b}$ & 14.75 & $3.12 \mathrm{~cd}$ & 22.43 & $125.62 a$ & $12.24 \mathrm{C}$ & 24.99 & $5.49 a$ & $6.49 a$ & $11.95 a$ & $45.68 \mathrm{a}$ \\
\hline $20 \mathrm{~cm}$ & 87.63 & $23.75 a$ & 9.24 & $14.51 a$ & 22.39 & $121.80 \mathrm{~b}$ & $15.15 b$ & 25.01 & $4.10 \mathrm{c}$ & $5.22 b$ & $9.32 \mathrm{C}$ & $43.95 b$ \\
\hline sX & 1.35 & 0.40 & 0.44 & 0.40 & 0.58 & 1.03 & 0.60 & 0.23 & 0.08 & 0.09 & 0.15 & 0.46 \\
\hline CV (\%) & 4.41 & 6.14 & 5.14 & 22.84 & 4.14 & 3.09 & 5.65 & 10.01 & 5.77 & 7.47 & 5.67 & 4.53 \\
\hline $\begin{array}{l}\text { Level of } \\
\text { Significance }\end{array}$ & NS & ** & NS & ** & NS & ** & ** & NS & ** & ** & ** & ** \\
\hline
\end{tabular}

In a column, figurers having same letter(s) or without letter do not differ significantly whereas figures with dissimilar letter(s) differ significantly as per DMRT at $5 \%$ level of probability.

** = Significant at $1 \%$ level of probability. NS =Not significant.

\section{Effect of hill to hill spacing}

Hill to hill spacing had significant effect on yield and yield contributing characters of rice (Table 1). Among the different yield attributes number of total tillers hill ${ }^{-1}$, non-effective tillers hill ${ }^{-1}$, grains panicle ${ }^{-1}$, sterile spikelet panicle ${ }^{-1}$ were affected significantly. The highest grain yield $\left(5.49 \mathrm{t} \mathrm{ha}^{-1}\right)$, straw yield $\left(6.49 \mathrm{t} \mathrm{ha}^{-1}\right)$ and biological yield $\left(11.95 \mathrm{t} \mathrm{ha}^{-1}\right)$ were obtained from $15 \mathrm{~cm}$ hill to hill spacing mainly due to the highest number of grains panicle ${ }^{-1}(125.62)$. The highest grain yield was possible due to combination of highest values for number of effective tillers hill ${ }^{-1}$, number of grains panicle and 1000-grain weight. The lowest grain yield $\left(2.11\right.$ tha $\left.^{-1}\right)$, straw yield $\left(4.02\right.$ tha $\left.^{-1}\right)$, biological yield $\left(6.13\right.$ tha $\left.^{-1}\right)$ and harvest index $(34.44 \%)$ were obtained from $2.5 \mathrm{~cm}$ hill to hill spacing due to fewest grains panicle ${ }^{-1}(82.50)$ and the highest number of sterile spikelets panicle ${ }^{-1}$ (27.83). The result is in agreement with the report of Rashid (2009) who stated that the rice (cv. BRRI dhan36) with $2.5 \mathrm{~cm}$ hill to hill spacing produced the lowest grain yield $\left(2.25 \mathrm{t} \mathrm{ha}^{-1}\right)$ under aerobic system of cultivation.

\section{Effect of row to row and hill to hill spacing}

The interaction effect of row to row and hill to hill spacing was significant for number of grains panicle ${ }^{-1}$, number of sterile spikelets panicle $e^{-1}$ and grain yield but not for other yield contributing characters (Table 2). The highest number of grains panicle ${ }^{-1}$ was found with $25 \mathrm{~cm} \times 5 \mathrm{~cm}$ spacing which was statistically similar to those with $20 \mathrm{~cm} \times 15 \mathrm{~cm}, 25 \mathrm{~cm} \times 15 \mathrm{~cm}$ and $25 \mathrm{~cm} \times 20 \mathrm{~cm}$ spacings. The fewest grains panicle $e^{-1}$ was obtained with $20 \mathrm{~cm} \times 2.5 \mathrm{~cm}$ spacing. The highest number of sterile spikelet panicle ${ }^{1}$ was found with $25 \mathrm{~cm} \times 2.5 \mathrm{~cm}$ spacing while the lowest was registered from $25 \mathrm{~cm} \times 20 \mathrm{~cm}$ spacing. The highest grain yield $\left(5.69 \mathrm{t} \mathrm{ha}^{-1}\right)$ was obtained from $25 \mathrm{~cm} \times 15 \mathrm{~cm}$. The result is at par with the result of Jalil (2008) who stated that the crop (cv.BRRI dhan29) with $25 \mathrm{~cm} \times 15 \mathrm{~cm}$ spacing produced the highest grain yield $\left(5.87 \mathrm{t} \mathrm{ha}^{-1}\right)$ under aerobic system of cultivation. These results might be due to availability of more nutrient, air and light in wider spacing which ultimately resulted in the production of more grain yield. The lowest grain yield $\left(2.11 \mathrm{t} \mathrm{ha}^{-1}\right)$ was obtained from $20 \mathrm{~cm} \times 2.5 \mathrm{~cm}$ which was identical to that from $25 \mathrm{~cm} \times 2.5 \mathrm{~cm}\left(2.11 \mathrm{t} \mathrm{ha}^{-1}\right)$. This might be due to highest number of sterile spikelets panicle $^{-1}$ (33.27). The highest sterility of spikelet at closest spacing reflects the high competition among the tillers for resources. The result is supported by the result of Rashid (2009) who stated that the crop (cv. BRRI dhan36) with $20 \mathrm{~cm} \times 2.5 \mathrm{~cm}$ spacing produced the lowest grain yield $\left(2.25 \mathrm{t} \mathrm{ha}^{-1}\right)$ under aerobic system of cultivation. The present result, therefore, showed that $25 \mathrm{~cm} \times 15 \mathrm{~cm}$ is the best for optimum growth and maximum yield for rice cv. BRRI dhan45. Mizan (2010) also found the highest yield at $25 \mathrm{~cm}$ $\times 15 \mathrm{~cm}$ spacing for transplanted boro rice cv. BRRI dhan45. In aman season, Rahman et al. (2004) 
found the best performance of a transplant rice cv. BRRI dhan39 at $25 \mathrm{~cm} \times 15 \mathrm{~cm}$ spacing. Hu et al. (1997) reported highest yield performance of rice at moderate spacing of $30 \mathrm{~cm} \times 17 \mathrm{~cm}$. The present study proves that rice could be cultivated at $25 \mathrm{~cm} \times 15 \mathrm{~cm}$ spacing for highest production in unpuddle aerobic condition. The present study further revealed that planting at $25 \mathrm{~cm} \times 15 \mathrm{~cm}$ spacing could be considered as the best practice for BRRI dhan45 both in aerobic direct seeded and puddle transplanted conditions.

Table 2. Interaction effect of row to row and hill to hill spacing on crop characters, yield and yield related parameters of BRRI dhan45 under aerobic system of cultivation in Boro season

\begin{tabular}{|c|c|c|c|c|c|c|c|c|c|c|c|c|}
\hline $\begin{array}{l}\text { Row to row } \times \text { hill to hill } \\
\text { pacing }\end{array}$ & $\begin{array}{l}\text { Plant } \\
\text { height } \\
(\mathrm{cm}) \\
\end{array}$ & $\begin{array}{c}\text { Total } \\
\text { tillers } \\
\text { hill-1 } 1 \text { (no.) } \\
\end{array}$ & \begin{tabular}{|c|} 
Effective \\
tillers hill-1-1 \\
(no.)
\end{tabular} & $\begin{array}{c}\text { Non-effective } \\
\text { tillers hill-1 } \\
\text { (no.) }\end{array}$ & $\begin{array}{l}\text { Panicle } \\
\text { length } \\
\text { (cm) }\end{array}$ & $\begin{array}{c}\text { Grains } \\
\text { panicle-1 }^{-1} \\
\text { (no.) }\end{array}$ & $\begin{array}{c}\text { Sterile } \\
\text { spikelets } \\
\text { panicle-1 (no.) }\end{array}$ & $\begin{array}{c}\begin{array}{c}1000-\text { grain } \\
\text { weight } \\
\text { (g) }\end{array} \\
\end{array}$ & $\begin{array}{c}\text { Grain } \\
\text { yield } \\
(\mathrm{t} \text { ha-1) }\end{array}$ & $\begin{array}{c}\text { Straw } \\
\text { yield } \\
\left(\mathrm{t} \mathrm{ha}^{-1}\right)\end{array}$ & 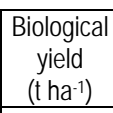 & \begin{tabular}{|c} 
Harvest \\
index \\
$(\%)$ \\
\end{tabular} \\
\hline $20 \mathrm{~cm} \times 2.5 \mathrm{~cm}$ & 89.05 & 16.44 & 12.63 & 3.82 & 20.87 & $84.42 \mathrm{~d}$ & $22.39 \mathrm{~b}$ & 23.77 & $2.11 f$ & 4.17 & 6.28 & 33.60 \\
\hline $20 \mathrm{~cm} \times 5 \mathrm{~cm}$ & 89.45 & 17.17 & 13.20 & 3.97 & 21.10 & $93.64 \mathrm{c}$ & $14.82 d$ & 25.25 & $4.44 d$ & 5.31 & 9.76 & 45.45 \\
\hline $20 \mathrm{~cm} \times 10 \mathrm{~cm}$ & 86.31 & 17.22 & 14.92 & 2.30 & 21.68 & $120.20 \mathrm{~b}$ & $9.82 \mathrm{fg}$ & 24.83 & $5.67 a b$ & 6.60 & 12.26 & 46.24 \\
\hline $20 \mathrm{~cm} \times 15 \mathrm{~cm}$ & 85.75 & 17.43 & 14.27 & 3.17 & 22.30 & $125.55 a$ & 11.19ef & 25.44 & $5.23 c$ & 6.50 & 11.73 & 44.60 \\
\hline $20 \mathrm{~cm} \times 20 \mathrm{~cm}$ & 84.33 & 24.19 & 8.99 & 15.20 & 23.44 & $118.25 b$ & $20.48 \mathrm{bc}$ & 25.35 & $4.05 \mathrm{e}$ & 5.20 & 9.25 & 43.77 \\
\hline $25 \mathrm{~cm} \times 2.5 \mathrm{~cm}$ & 85.66 & 17.32 & 13.01 & 4.31 & 23.24 & $80.59 d$ & $33.27 a$ & 25.21 & $2.11 f$ & 3.87 & 5.97 & 35.29 \\
\hline $25 \mathrm{~cm} \times 5 \mathrm{~cm}$ & 85.50 & 17.88 & 12.70 & 5.18 & 23.18 & $126.16 a$ & $18.96 \mathrm{c}$ & 24.91 & $4.50 \mathrm{~d}$ & 5.46 & 9.96 & 45.18 \\
\hline $25 \mathrm{~cm} \times 10 \mathrm{~cm}$ & 86.15 & 18.32 & 15.10 & 3.23 & 22.17 & $117.02 b$ & $8.40 \mathrm{~g}$ & 24.60 & $5.32 \mathrm{bc}$ & 6.31 & 11.63 & 45.75 \\
\hline $25 \mathrm{~cm} \times 15 \mathrm{~cm}$ & 89.35 & 18.30 & 15.24 & 3.07 & 22.55 & $125.68 \mathrm{a}$ & 13.29de & 24.54 & $5.69 a$ & 6.48 & 12.18 & 46.75 \\
\hline $25 \mathrm{~cm} \times 20 \mathrm{~cm}$ & 90.92 & 23.31 & 9.48 & 13.83 & 21.33 & $125.35 a$ & $9.82 \mathrm{fg}$ & 24.66 & 4.14de & 5.24 & 9.38 & 44.14 \\
\hline $\mathrm{s}_{\bar{X}}$ & 1.91 & 0.56 & 0.62 & 0.57 & 0.82 & 1.46 & 0.85 & 0.32 & 0.12 & 0.13 & 0.21 & 0.65 \\
\hline CV (\%) & 4.41 & 6.14 & 5.14 & 22.84 & 4.14 & 3.09 & 5.65 & 10.01 & 5.77 & 7.47 & 5.67 & 4.53 \\
\hline Level of Significance & NS & NS & NS & NS & NS & ** & ** & NS & ** & NS & NS & NS \\
\hline
\end{tabular}

In a column, figurers having same letter(s) or without letter do not differ significantly whereas figures with dissimilar letter(s) differ significantly as per DMRT at $5 \%$ level of probability. ${ }^{\star *}=$ Significant at $1 \%$ level of probability. NS =Not significant.

\section{Conclusion}

Based on the result of the present study it could be concluded that the highest grain yield of rice cV. BRRI dhan 45 could be obtained by planting at $25 \mathrm{~cm} \times 15 \mathrm{~cm}$ spacing under aerobic system of cultivation in boro season.

\section{References}

BBS (Bangladesh Bureau of Statistics). 2011. Statistical Year Book of Bangladesh. Bur. Stat., Stat. Div., Min. Plan., Govt. People's Repub., Bangladesh, Dhaka. pp. 47.

Bouman, B.A.M., Peng, S., Castaneda, A.R. and Visperas, R.M. 2005. Yield and water use of irrigated tropical aerobic rice systems. Agric. Water Manage. 74:87-105.

Hu, W.H., Wu, C.S. Deng, S.H. and He, S.H. 1997. A study on the growth characteristics of rice at different populations. J. Jelin. Agril. Univ. 19(1) : 23-27.

Jalil, M.A. 2008. Effect of spacing and rate of fertilizer application on yield performance of Boro rice (cv. BRRI Dhan29) under aerobic system of cultivation. M.S. Thesis, Dept. Agron., Bangladesh Agril. Univ., Mymemsingh. pp. 48-49.

Miah, M.H.N., Karim, M.A., Rahman, M.S. and Islam, M.S. 1990. Performance of Nizersail mutants under different row spacing. Bangladesh J. Train. and Dev. 3(2): 31-34.

Mizan, M.R. 2010. Effect of nitrogen and plant spacing on the yield of boro rice cv. BRRI dhan45. M. S. Thesis, Dept. Agron., Bangladesh Agril. Univ., Mymemsingh. pp. 45-47.

Peng, S., Bouman, B.A.M., Visperas, R.M. Castaneda, A.R., Nie, L. and Park, H.K. 2006. Comparison between aerobic and flooded rice in the tropics: Agronomic performance in an eight-season experiment. Field Crops Res. 96:252-259.

Rahman, M.M., Islam, M.M. and Aktar, F.M.F. 2004. Effect of hill spacing and nitrogen level on seed yield and yield attributes of transplant aman rice. Bangladesh J. Crop. Sci. 13-15: 95-101.

Rahman, M.M., Taher, M.A. and Ahammad, K.U. 2008. Growth response of aman rice cv. BRRI dhan39 to date of transplanting and hill spacing. Bangladesh J. Prog. Sci.Technol. 6(1): 121-124.

Rahman, M.M. and Taher, M.A. 2008. Effect of date of transplanting and hill spacing on seed yield of transplant aman rice cv. BRRI dhan39. Bangladesh J. Agricul. 1(1) : 89-93.

Rashid, M.H. 2009. Effect of spacing on the growth and yield of Boro rice (cv. BRRI dhan 36) under aerobic system of cultivation. M.S. Thesis, Dept. Agron., Bangladesh Agril. Univ., Mymensingh. pp. 45-47.

Sattar, M.A. 2009. Cost effective, environment friendly boro rice cultivation. The Daily Star. p. 13, 30 May 2009.

Verma, A.K., Pandey, N. and Tripathi, J. 2002. Effect of transplanting spacing and number of seedling on productive tiller, spikelet sterility, grain yield and harvest index of hybrid rice. Intl. Rice Res. Notes. 27(1) : 51.

Zhao, G.P., Chen, Z.Y. and Zhang, G.P. 1998. Effect of plant density on population structure and light utilization by seedlings of rice raised in dry nursery. J. Zhejiang Agril. Univ. 24(4): 349-354. 